\title{
An Immunocytochemical and In Situ Hybridization Analysis of Annexin 1 Expression in Rat Mast Cells: Modulation by Inflammation and Dexamethasone
}

\author{
Sonia M. Oliani, Helen C. Christian, John Manston, Roderick J. Flower, and \\ Mauro Perretti
}

Department of Biology (SMO), IBILCE UNESP, São José do Rio Preto, Brazil; and Department of Human Anatomy and Genetics (HCC), University of Oxford, Oxford, Department of Neuroscience (JM), Queen Mary and Westfield College, and Department of Biochemical Pharmacology (SMO, RJF, MP), The William Harvey Research Institute, St. Bartholomew's and The Royal London School of Medicine and Dentistry, London, United Kingdom

\begin{abstract}
SUMMARY: The presence and localization of the anti-inflammatory protein annexin 1 (also known as lipocortin 1) in perivenular rat mast cells was investigated here. Using the rat mesenteric microvascular bed and a combination of morphologic techniques ranging from immunofluorescence to electron microscopy analyses, we detected the presence of annexin 1 in discrete intracellular sites, both in the nucleus and in the cytoplasm. In resting mast cells, most of the protein pool (approximately $80 \%$ of the cytosolic portion) was localized to cytoplasmic granules. In agreement with other cell types, treatment of rats with dexamethasone $(0.2 \mathrm{mg} / \mathrm{kg}$, ip) increased annexin 1 expression in mast cells, inducing a remarkable appearance of clusters of protein immunoreactivity. This effect was most likely the result of de novo protein synthesis as determined by an increase in mRNA seen by in situ hybridization. Triggering an ongoing experimental inflammatory response ( $0.3 \mathrm{mg}$ of carrageenin, ip) increased annexin $1 \mathrm{mRNA}$ and protein levels. In conclusion, we report for the first time the localization of annexin 1 in connective tissue mast cells, and its susceptibility not only to glucocorticoid hormone treatment, but also to an experimental acute inflammatory response. (Lab Invest 2000, 80:1429-1438).
\end{abstract}

\begin{abstract}
$A$ nnexin 1 (ANX-1; previously known as lipocortin 1), a 37-kd member of the annexin super-family of proteins, originally evoked interest as one of the "second messengers" responsible for the antiinflammatory actions of the glucocorticoid hormones. Subsequent research has shown that ANX-1 plays a major regulatory role in systems as diverse as cellgrowth regulation and differentiation, neutrophil migration, CNS responses to cytokines, neuroendocrine secretion, and neurodegeneration (Ahluwalia et al, 1996; Buckingham, 1996). The role of ANX-1 in mediating glucocorticoid-induced effects in these systems has been demonstrated using immunoneutralization and antisense strategies, and by the ability of highly purified or recombinant ANX-1 and ANX-1-derived fragments to mimic steroid actions. Originally, ANX-1 actions were ascribed to a potent inhibitory effect on prostaglandin formation (Flower and Blackwell, 1979),
\end{abstract}

\section{Received May 23, 2000}

This work was supported by the Arthritis Research Campaign United Kingdom (ARC, Grant P0535). RJF is a principal fellow of the Wellcome Trust. MP is a postdoctoral fellow of the ARC. SMO was supported by Fundação de Amparo à Pesquisa do Estado de São Paulo (FAPESP), Brazil.

Address reprint requests to: Dr. M. Perretti, Department of Biochemical Pharmacology, The William Harvey Research Institute, Charterhouse Square, London EC1M 6BQ, United Kingdom. Fax: 44207882 6076; E-mail:M.Perretti@qmw.ac.uk but it is now clear that the protein can alter several other aspects of cell function (for a recent review, see Ahluwalia et al, 1996).

ANX-1 differs from other members of the annexin family in that it is mainly localized in the cytoplasmic compartment of resting neutrophils and macrophages, but after cell activation it is translocated to the cell-surface (Peers et al, 1993) and extracellular fluids (Vergnolle et al, 1995). Human neutrophils can externalize substantial amounts of the protein (more than $50 \%$ ) upon adhesion to monolayers of endothelial cells (Perretti et al, 1996b).

Few studies have investigated the cellular distribution of ANX-1 by ultrastructural analyses. In resting macrophages, ANX-1 was found by immunocytochemical detection to be mainly distributed in patches in the cytoplasm. However, upon phagocytosis of yeast particles or Escherichia coli organisms, the protein was rapidly translocated and concentrated around the phagosomes (Harricane et al, 1996). Human neutrophils phagocytosing zymosan (yeast particles) translocates ANX-1 to the plasma membrane (Kaufman et al, 1996). Morphologic and biochemical evidence exist for a partial nuclear localization of ANX-1 in resting endothelial cells (Raynal et al, 1992). Recently, Traverso et al (1998) demonstrated ANX-1 throughout the cytoplasm and processes of folliculostellate cells in the rat anterior pituitary. 
Despite its presence in several cell types, there have been no reports on the localization of ANX-1 or its expression in mast cells. This is surprising in view of the important role that mast cells play in the initiation of the inflammatory response (for a recent review, see Galli et al, 1999), and the fact that ANX-1 is a potent anti-inflammatory mediator able to regulate several aspects of the host inflammatory reaction (Flower and Rothwell, 1994; Perretti, 1997). A single study has shown that incubation of human mast cell with interleukin-2 for 12 hours inhibited histamine release evoked by compound 48/80, accompanied by an increase in cell-associated ANX-1 levels assessed by Western blotting (Tasaka et al, 1994). Here, we systematically monitored ANX-1 expression in mast cells within the rat mesenteric vascular bed to determine its precise cellular localization in mast cells. We also investigated the modulation of ANX-1 by an experimental inflammatory reaction or treatment with the anti-inflammatory synthetic glucocorticoid hormone, dexamethasone.

\section{Results}

\section{ANX-1 Expression in Rat Mast Cells}

A typical mast cell with metachromatic granules in close vicinity to an inflamed mesenteric vessel is shown in Figure 1, A and B. Initially, we used immunofluorescence microscopy to examine whether the polyclonal antibody to ANX-1, LCS3, was effective in detecting ANX-1 immunoreactivity in rat mast cells. Strong immunofluorescence was visualized throughout the cytoplasm of mesenteric mast cells (Fig. 1C). In contrast, no immunofluorescence was detected in sections incubated with nonimmune sheep serum (NSS) or with LCS3 preadsorbed with ANX-1, indicating a high degree of specificity for LCS3 in these experimental samples (data not shown).

We then analyzed ANX-1 expression by postembedding immunogold labeling to define the subcellular localization of ANX-1 in connective tissue mast cells. We validated the fixation protocol for the preservation of both mast cell morphology and the ANX-1 antigenicity; the fixative mixture used gave the best compromise between strong immunofluorescence and low background. Control rats treated with PBS were evaluated first. Strong ANX-1 immunoreactivity was confirmed in intact mesenteric mast cells. Gold particles were mainly detected intracellularly; immunoreactivity was localized predominantly within electron-dense granules and, to a lesser amount, throughout the cytosol (Fig. 2, A and C). Some immunoreactivity was also found associated with the plasma membrane and within the nucleus. Table 1 shows the density of immunogold particles measured in these animals. No labeling was detected in sections incubated with NSS alone (Fig. 2B).

\section{ANX-1 Expression in Mast Cells After an Inflammatory Reaction}

Because in vitro mast cell incubation with interleukin-2 increases ANX-1 levels, and therefore reduces the degree of histamine release (Tasaka et al, 1994), we investigated whether induction of an experimental inflammatory reaction, with consequent mast cell degranulation, was associated with mobilization of ANX-1.

Rat mesenteries were inflamed with carrageenin. Four hours after induction of the inflammatory response, most of tissue mast cells seemed to be activated. However, despite this large degree of cell degranulation, ANX-1 remained essentially cellassociated (Fig. 3A). A high density of ANX-1 immunoreactivity was seen at the level of the granule matrices (Fig. 3A, inset). Table 1 shows the quantitative analysis of ANX-1 expression in the three mast cell compartments 4 hours after carrageenin administration. A significant $(p<0.05)$ increase in ANX-1 immunoreactivity was seen in both the cytoplasm and granule compartments.

A different polyclonal serum, LCPS1, was used to confirm the specificity of the ANX-1 immunoreactivity. LCPS1 recognizes only the intact full-length protein and had a higher degree of reactivity with cytosolic ANX-1 (Fig. 3). Figure 3A shows a good association of ANX-1 with granules of different electron-density of the mast cell, visualized with the LCPS1 antibody, agreeing with what was found with the LCS3 antibody (Fig. 2A). Analysis of the immunogold particles counted with LCS3 and LCPS1 in six distinct preparations showed no differences between the two antibodies, with $158.7 \pm 38.3$ and $144.8 \pm 13.2$ gold particles per mast cell for LCS3 and LCPS1, respectively ( $n=6$, not significant). Similarity in immunoreactivity between the two antibodies was also seen in inflamed tissues.

A close interaction between an activated mast cell and an adjacent fibroblast is also seen in Figure $3 \mathrm{~A}$. ANX-1 immunoreactivity was also detected at the points of contact between these two cells, and some gold particles were seen along the cytoplasmic filopodia. The fibroblast cytoplasm was also immunoreactive for ANX-1 (Fig. 3A).

\section{ANX-1 Expression in Mast Cells After Dexamethasone Treatment}

An increase in ANX-1 immunoreactivity was detected in mast cells of steroid-treated animals. Table 1 shows the quantitative data with a predominant increase in the granular localization of the protein. The characteristic pattern of ANX-1 expression observed in these cells after administration of the steroid is shown in Figure 3B. Clusters of ANX-1 immunoreactivity in the matrix of cytoplasmic granules were selectively detected after treatment with this synthetic steroid (Fig. 3B inset). 

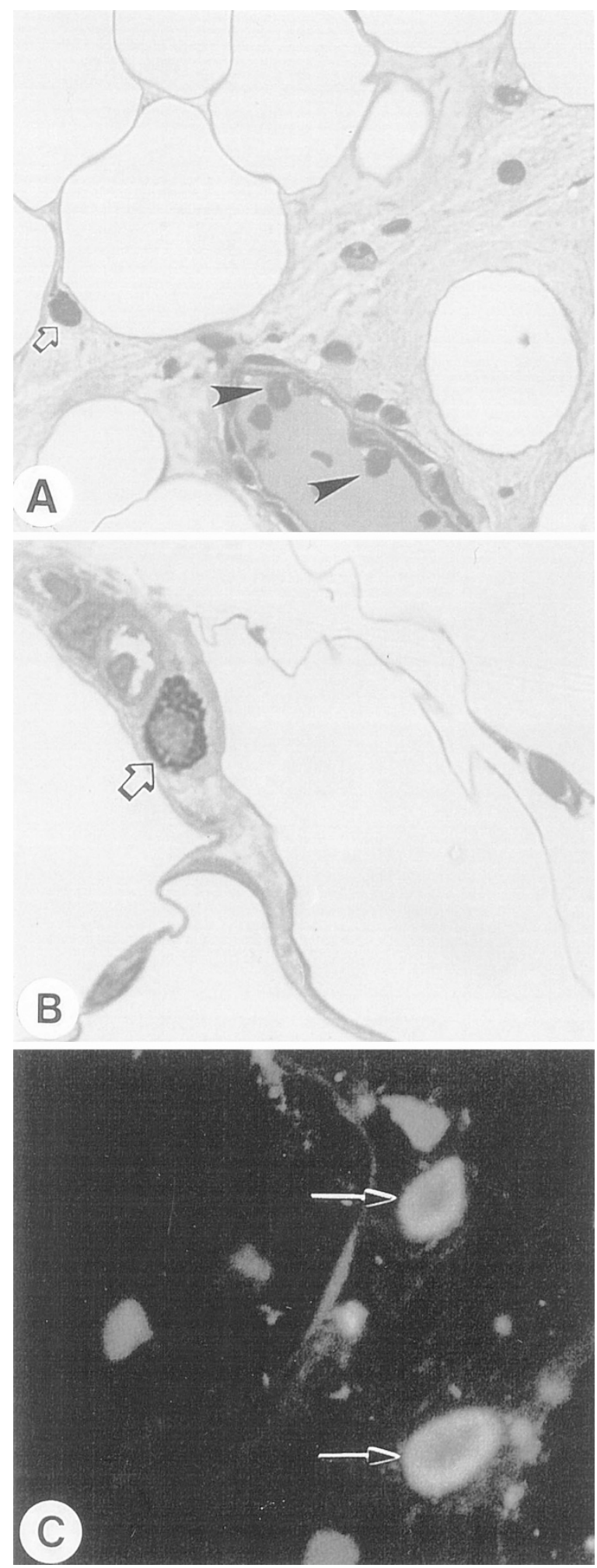

\section{Figure 1.}

Light micrographs of rat mesenteries showing mast cell localization and annexin 1 (ANX-1) immunoreactivity. A, Mast cell localization (arrow) near post-capillary venules (original magnification, $\times 160$ ). Neutrophils are indicated by arrowheads. B, Mast cell with metachromatic granules (arrow) at higher magnification $(\times 1500)$. Sections $(0.5 \mu \mathrm{m}$ thick) were stained with toluidine blue. $C$, Immunofluorescence labeling of ANX-1 in sections of rat mesentery by a polyclonal antibody to ANX-1 raised against full-length human recombinant ANX-1 (LCS3). ANX-1 immunoreactivity is present in the mast cell cytoplasm (arrows) and shown in yellow (original magnification, $\times 1500$ ).

\section{In Situ Hybridization (ISH) for ANX-1 in Inflamed Mast Cells}

Finally, we investigated whether mast cells express ANX-1 messenger RNA and whether expression was altered after either carrageenin-induced inflammation or treatment with dexamethasone.

An ISH protocol was validated using short oligonucleotide probes directed against portions of the $\mathrm{N}$-terminus of ANX-1. No signal was detected in mesentery collected from PBS-treated animals, used as a negative control for the experimental inflammation (not shown). Similarly, no signal was seen in carrageenin-treated tissues with sense oligonucleotides, used as a negative control for the ISH reaction (not shown). In contrast, strong signals were found in mast cells from mesenteric tissues collected from carrageenin-treated rats (Fig. 4A). Thus, activated mast cells were strongly positive for ANX-1 mRNA. This feature was also evident after steroid treatment (Fig. 4C). The identity of the cell type was confirmed by staining of identical tissues with toluidine blue, confirming the mast cell localization of the ANX-1 mRNA (Fig. 4, D and E). Finally, a strong reactivity for ANX-1 mRNA was also seen in tissue fibroblasts (Fig. 4B). Semi-quantitative analysis of mesenteric flat mount preparations indicated that $90 \%$ of fibroblasts and approximately $50 \%$ to $60 \%$ of mast cells had ANX-1 mRNA after carrageenin injection.

\section{Discussion}

In this study, we investigated for the first time the localization and disposition of ANX-1 in rat mast cells. We report that connective tissue mast cells are strongly immunoreactive for ANX-1 and that new synthesis occurs after an inflammatory insult. ANX-1 expression in this cell type is also regulated by the glucocorticoid dexamethasone.

ANX-1, the first member of the lipocortins or annexins super-family of proteins to be cloned, is widely distributed throughout the body. Nonetheless, this protein is not ubiquitous, and higher levels are found in certain specialized tissues and cells (Fava et al, 1989). Human and rodent blood neutrophils and monocytes have much higher levels of ANX-1 than circulating lymphocytes (Goulding et al, 1990; Morand et al, 1995; Perretti and Flower, 1996). Tissue-dwelling cells have higher ANX-1 contents than their circulating counterparts. This has been demonstrated from peritoneal macrophages with respect to circulating monocytes (Perretti and Flower, 1996) and for eosinophilic polymorphonuclear leukocytes (Das et al, 1997). It therefore seems that the process of cell differentiation into specific tissue sites is accompanied by synthesis of additional ANX-1.

We clearly demonstrated that mast cells contain ANX-1, and we also investigated the sub-cellular localization of the protein. Using rat mesenteric preparations, strong ANX-1 immunoreactivity was seen in the perivenular mast cell. By electron microscopic (EM) analysis, it was found that the large majority of 


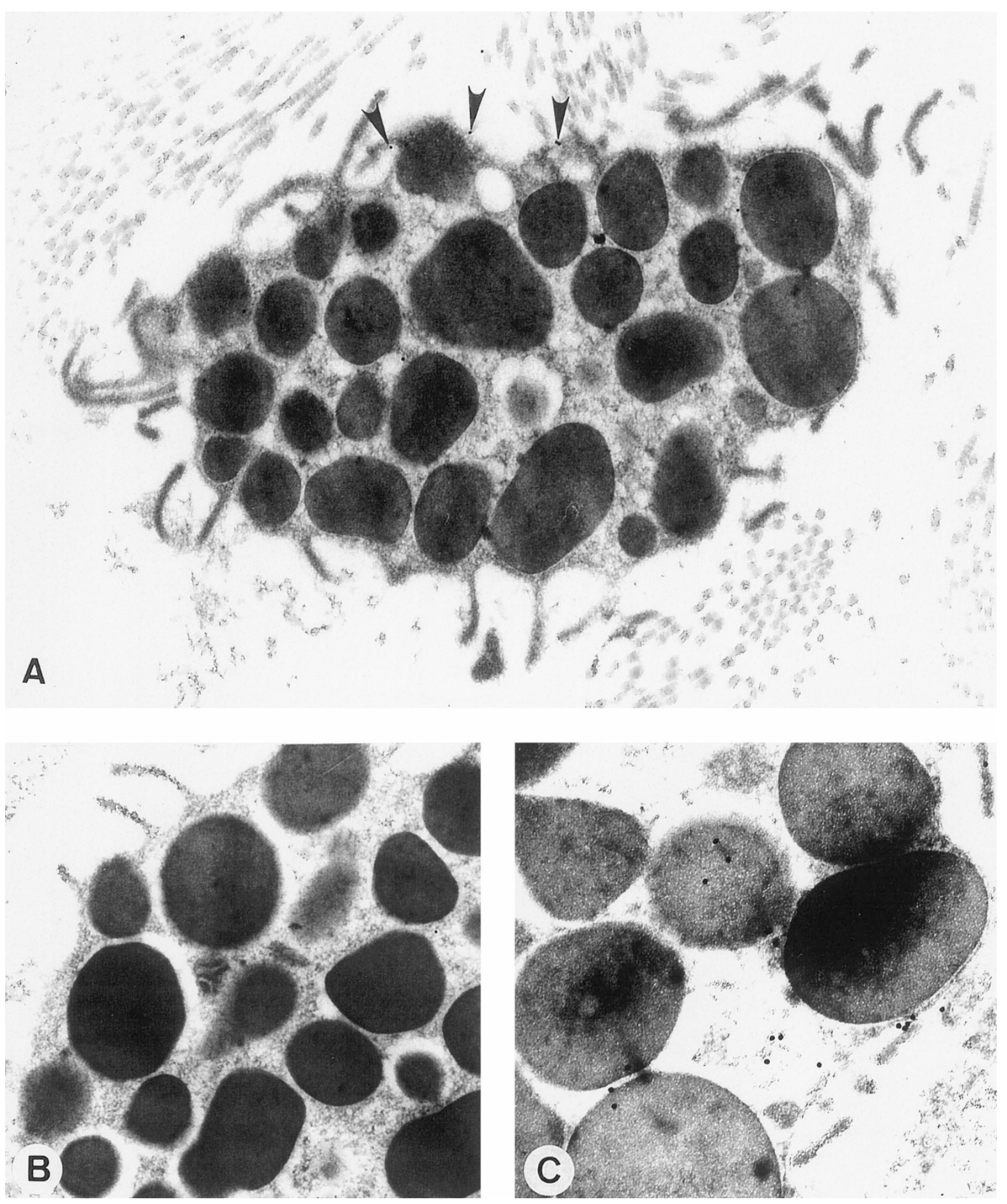

\section{Figure 2.}

Electron micrographs showing immunogold detection of ANX-1 using LCS3 in mast cells. A, Mast cell view showing electron-dense granules and plasma membrane-associated gold particles (arrowheads) (original magnification, $\times 20,000$ ). B. Control section incubated with nonimmune sheep serum. No gold labeling was observed (original magnification, $\times 20,000$ ). $C$. High power view showing gold particles in mast cell granules and throughout the cytoplasm (original magnification, $\times 50,000)$.

ANX-1 was confined to the cytosol of rat mast cells, with a strong association with a variety of granules with different electron-density characteristics.

Immunoreactivity obtained with both LCS3 and LCPS1 antibodies was compared. The polyclonal antibody LCS3 has been successfully used to monitor ANX-1 expression by EM in A549 cells (Traverso et al,
1998) and human neutrophils (Perretti et al, 2000). Here we also used LCPS1, a sheep serum raised against the specific N-terminal region of ANX-1 (Perretti and Flower, 1996). The strong immunoreactivity observed with LCPS1 in intact mast cells confirms the data obtained (a problem when working with this class of highly homologous proteins) and demonstrates that 
Table 1. Density of ANX-1 Immunogold Particles in Mast Cells in Control Animals, Rats Treated with Carrageenin or with Dexamethasone

\begin{tabular}{lccc}
\hline & \multicolumn{3}{c}{ ANX-1 immunoreactivity in mesenteric mast cells $\left(\right.$ gold particles/ $\mu \mathrm{m}^{2}$ ) } \\
\cline { 2 - 4 } \multicolumn{1}{c}{ Treatment } & \multicolumn{1}{c}{ Cytoplasm } & Granule & Nucleus \\
\hline PBS & $2.60 \pm 0.35(10)$ & $8.87 \pm 0.87(10)$ & $12.30 \pm 1.53(5)$ \\
Carrageenin & $12.30 \pm 1.49(10)^{\star}$ & $23.83 \pm 2.87(10)^{\star}$ & $15.58 \pm 2.39(5)$ \\
Dexamethasone & $3.77 \pm 0.87(10)$ & $42.61 \pm 2.97(10)^{\star}$ & $17.40 \pm 1.74(5)$ \\
\hline
\end{tabular}

Data are mean \pm SEM of $n$ distinct mast cells analyzed in the mesenteric tissue of control rats (PBS treatment), rats subjected to inflammation (carrageenan 1.5 $\mathrm{mg} / \mathrm{kg}$ ip, 4 hours), or animals treated with dexamethasone $(0.2 \mathrm{mg} / \mathrm{kg} \mathrm{sc}, 4$ hours).

${ }^{\star} p<0.05$ vs PBS injected rats.

it is intact ANX-1 that is present in the intracellular granules, cytoplasm, and nucleus.

The overall distribution observed for ANX-1 in rat mast cells generally agrees with observations made in other cell types. A partial nuclear localization for ANX-1 has been reported in endothelial cells (Raynal et al, 1992) and in human neutrophils (Perretti et al, 2000). Nonetheless, the immunofluorescence data indicate that the overall nuclear localization of ANX-1 is modest in comparison to the other sub-cellular compartments.

The present finding is of importance because no studies have reported ANX-1 presence in mast cells. One exception is the investigation of Tasaka et al (1994), who demonstrated by Western blotting analysis that ANX-1 was present in rat peritoneal mast cells, and that it was increased after cell incubation with interleukin-2. This increase in ANX-1 was associated with a lower mast cell degranulation after stimulation with compound 48/80. Based on this, in the second part of our study, we monitored ANX-1 localization and synthesis after mast cell degranulation.

Carrageenin provokes an inflammatory reaction characterized by mast cell stimulation and degranulation along with extensive white blood cell infiltration ( $\mathrm{Di}$ Rosa and Sorrentino, 1968). Mast cells can release an array of mediators, including histamine, plateletactivating factor, and tumor necrosis factor- $\alpha$, which can induce both a rapid and a delayed inflammatory response, measured in terms of leukocyte rolling, adhesion, and emigration (Galli et al, 1999; Kubes and Granger, 1996). Additionally, carrageenin seems to be a pertinent inflammogen because the inflammatory response it activates is inhibited by exogenous administration of human recombinant ANX-1 (Becherucci et al, 1993; Cirino et al, 1989).

Inflammation of the mesenteric vascular bed with carrageenin provoked mast cell activation. In these cells, ANX-1 immunoreactivity was still very strong and essentially in agreement with what was observed in intact mast cells. Remarkably, ANX-1-immunoreactive gold particles were located within granule matrices and were also found at the level of the adhesion points between the activated mast cells and an adjacent fibroblast. Thus, during the present conditions of experimental inflammation, mast cell-derived ANX-1 remained mainly cell associated. The interrelationship between mast cells and fibroblasts is not novel, for instance, the formation of gap junctions has been demonstrated during development (Oliani et al, 1995).

We also tested whether a synthetic glucocorticoid could modulate ANX-1 expression in rat mast cells. ANX-1 synthesis is under the partial control of glucocorticoids. The levels of ANX-1 are reduced in several tissues of adrenalectomized rats (Vishwanath et al, 1992) and augmented in white blood cells after systemic administration of dexamethasone (Perretti and Flower, 1996). Additionally, glucocorticoidmediated synthesis of ANX-1 has been demonstrated in several cell types (reviewed in Ahluwalia et al, 1996). Here, we found that treatment of rats with an antiinflammatory dose of dexamethasone, previously validated using the rat mesenteric vascular bed (Tailor et al, 1997), augmented ANX-1 protein expression. The functional reason for this increment is unclear. Mast cells respond differently to in vivo treatment with this steroid in relation to the stimulus employed to achieve activation; phospholipase $\mathrm{A}_{2}$-induced, but not compound $48 / 80$-induced mast cell degranulation is inhibited by dexamethasone (Perretti et al, 1990). An interesting morphologic observation was the existence of clusters of ANX-1 immunoreactivity after administration of dexamethasone. The steroid increased the overall granular expression of ANX-1.

Finally, the data discussed above were reinforced by ISH experiments. This is the first study to report ISH analysis of ANX-1 mRNA expression in any type of tissue. During the experimental inflammatory reaction, but not in tissues collected from PBS-treated animals, we observed a strong signal for ANX-1 mRNA in mast cells and fibroblasts, using digoxigenin-labeled ANX-1 oligonucleotides. This data was reproducible and observed throughout the tissue. In particular, almost every fibroblast contained ANX-1 mRNA. In contrast to mast cells, fibroblasts have long been known to possess ANX-1 (Philipps et al, 1989), and here we report that these cells react to experimental inflammation by increasing the synthesis of this protein. ISH has been successfully used to detect mRNA of specific mediators, including stem cell factor (Zhang et al, 1998). Here, we add ANX-1 as a mediator that is rapidly synthesized upon activation. The increase in ANX-1 mRNA expression detected during the peritonitis could be due to a rise in circulating corticosterone. However, it is more likely that locally produced cytokines, eg, interleukin-6 (Utsunomiya et al, 1991), may contribute to ANX-1 gene 

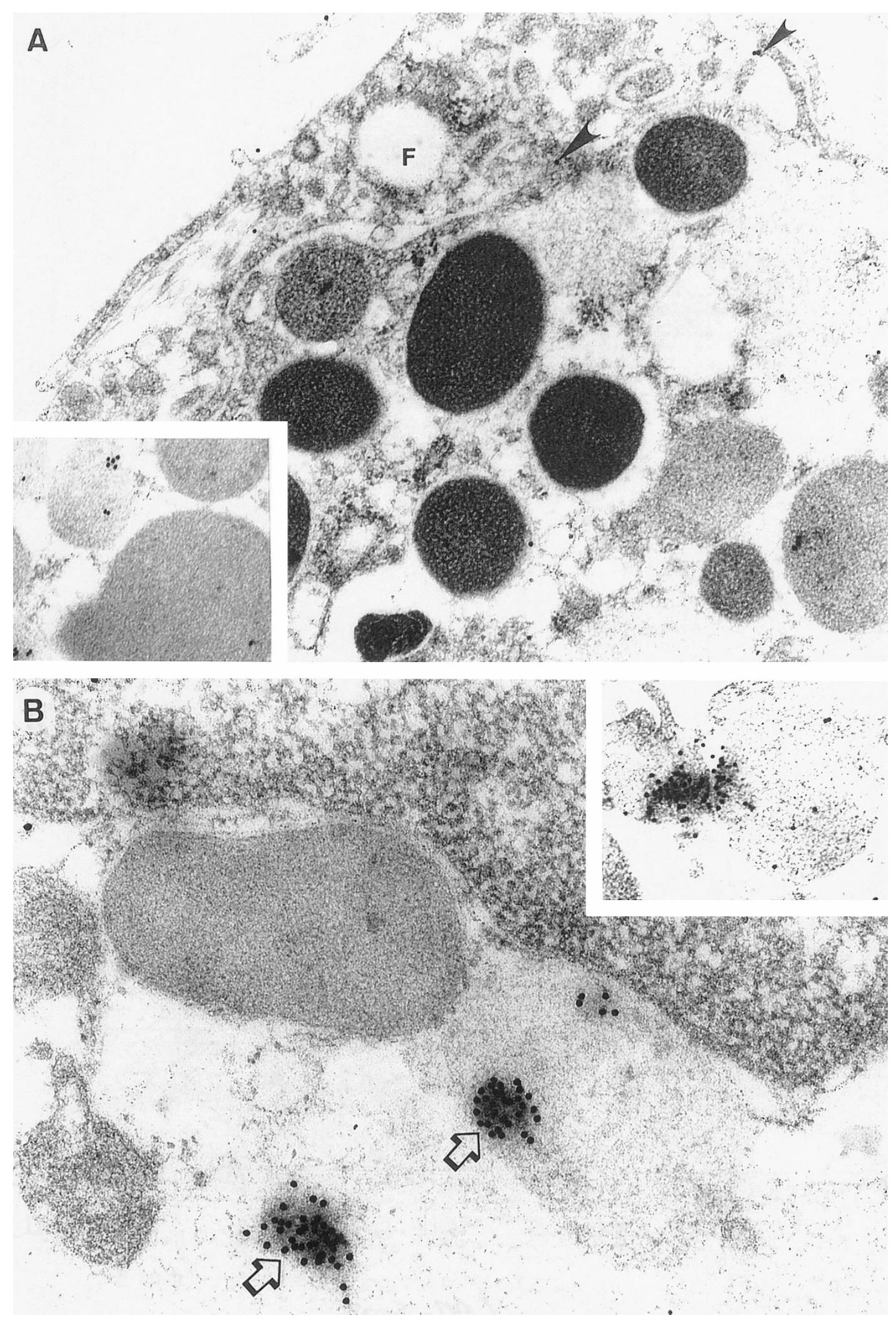

\section{Figure 3.}

Modulation of ANX-1 protein expression in rat mesenteric mast cells. A, Effect of carrageenin injection. Electron micrograph of a mast cell immunoreacted with LCPS1, a polyclonal sheep serum raised against the specific ANX-1 N-terminus. Shown are granules of different electron densities, characteristic of the activated mast cell, and ANX-1 immunoreactivity at points of contact between mast cell and an adjacent fibroblast (arrowheads). Immunogold particles can also be seen in the fibroblast cytoplasm (F) (original magnification, $\times 50,000$ ). Inset: Localization of immunogold particles within the granule matrices (original magnification, $\times 50,000$ ). $B$, Effect of treatment with dexamethasone $(0.2 \mathrm{mg} / \mathrm{kg}$, ip, 4 hours after treatment). ANX-1 immunoreactivity appears with these characteristic aggregates within the granules (arrows) (original magnification, $\times 90,000$ ). Inset: Another example of cluster ANX-1 immunoreactivity in two cytoplasmic granules (original magnification, $\times 50,000)$. 


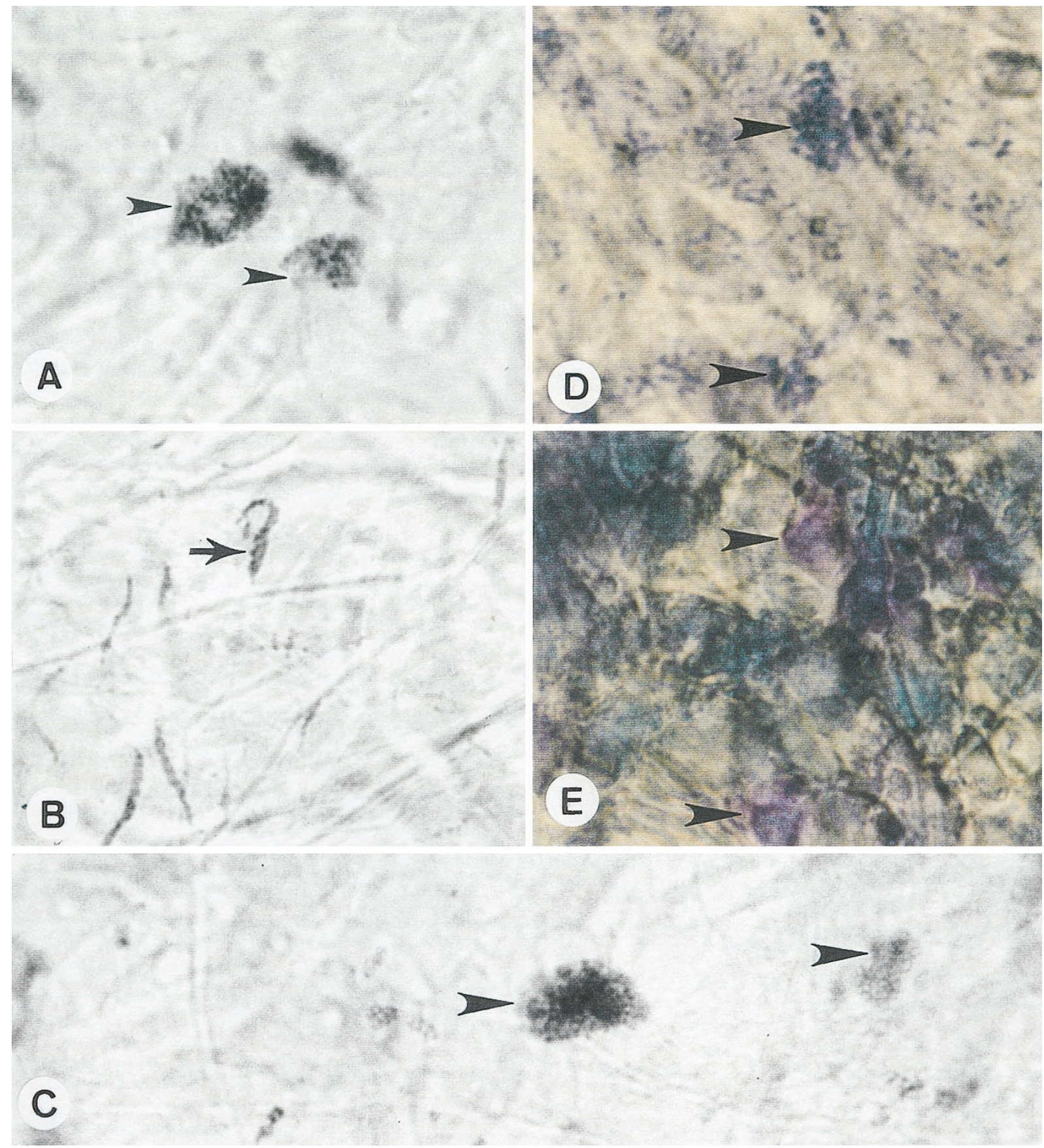

\section{Figure 4.}

Modulation of ANX-1 mRNA expression assessed by ISH in flat mounts of rat mesenteries. A, Strong signals for ANX-1 mRNA is detected in mast cells after tissue incubation with a specific antisense oligonucleotide (arrowheads) (original magnification, $\times 1800$ ). $B$, A representative fibroblast with ANX-1 mRNA (arrow) (original magnification, $\times 1500)$. In both cases, tissues were obtained from carrageenin-treated rats. C, ANX-1 mRNA in mast cells of dexamethasone-treated rats $(0.2 \mathrm{mg} / \mathrm{kg}$ ip, 4 hours after treatment). $D$, Intense signal for ANX-1 mRNA is detected in mast cells from rats treated with dexamethasone after tissue incubation with a specific antisense oligonucleotide (arrowheads). $E$, The same cells shown in $D$, stained with toluidine blue after the ISH reaction (panels $C, D$, and $E$, original magnification, $\times 1800)$.

expression, as recently reported in cell culture systems (Solito et al, 1998). We cannot exclude the possibility that cytokines other than interleukin- 6 may play a role, for instance, in our hands, tumor necrosis factor also induces ANX-1 synthesis in U937 cells (unpublished observation). Finally, we observed dexamethasone induction of ANX-1 mRNA in mast cells. After staining flat mount preparations with toluidine blue at the end of the
ISH reaction, the identity between connective tissue mast cells and the ANX-1 mRNA was confirmed.

\section{Materials and Methods}

\section{Animals}

Male Sprague-Dawley rats (200 to $250 \mathrm{~g}$ body weight; Banton and Kingsman, Hull, United Kingdom) main- 
tained on a standard chow pellet diet with tap water ad libitum were used for all experiments. Animals were housed four per cage in a room with controlled lighting (lights on 8:00 to 20:00 hours) and temperature $\left(21^{\circ} \mathrm{C}\right.$ to $23^{\circ} \mathrm{C}$ ), and used 2 to 3 days after arrival in the colony. Animal work was performed according to Home Office regulations (Guidance on the operation of animals, Scientific Procedures Act, 1986).

\section{Model of Inflammation}

Experimental peritonitis was induced by ip injection of $1.5 \mathrm{mg} / \mathrm{kg}$ carrageenin (type lambda, Sigma Chemical Company, Poole, Dorset, United Kingdom) in PBS. Carrageenin was chosen because it provokes mast cell activation (eg, see Di Rosa and Sorrentino, 1968). Control animals were injected ip with PBS rather than carrageenin. In all cases, rats were killed 4 hours later by $\mathrm{CO}_{2}$ exposure. Mesenteries were removed and cut into small fragments for immunofluorescence studies. For ISH and immunocytochemical studies, animals were first anaesthetized with sodium pentobarbital (50 $\mathrm{mg} / \mathrm{kg}$ ) and perfused (equipment cleaned with ethanol, $1 \%$ SDS, and sterile distilled water) through the left ventricle of the heart with sterile saline $(30$ to $50 \mathrm{ml}$ per rat) for 30 to 60 seconds, followed by a slow (5 to 10 minutes) infusion of $100 \mathrm{ml}$ of cold paraformaldehyde (2\% in PBS).

\section{Treatment with Dexamethasone}

Dexamethasone (Sigma Chemical Company) was administered ip at the dose of $200 \mu \mathrm{g} / \mathrm{kg}$ in $0.3 \mathrm{ml}$ of PBS, 4 hours before tissue collection. This dose was chosen because it was previously shown to be effective in controlling experimental inflammation in the rat mesentery (Tailor et al, 1997). Control rats received an equal volume of sterile PBS without the steroid. Tissue collection and handling was performed as described above.

\section{Fixation, Processing, and Embedding for Immunofluorescence and EM}

Fragments of mesentery were fixed in 4\% paraformaldehyde and $0.5 \%$ glutaraldehyde, $0.1 \mathrm{M}$ sodium cacodylate buffer, $\mathrm{pH} 7.4$, for 24 hours at $4^{\circ} \mathrm{C}$, washed in sodium cacodylate, dehydrated through a graded series of ethanol, and embedded in LR Gold resin (London Resin Company, Reading, Berkshire, United Kingdom). Sections (0.5 $\mu \mathrm{m}$ thick) were prepared for immunofluorescence and stored at $-70^{\circ} \mathrm{C}$. For EM, sections (approximately $90 \mathrm{~nm}$ thick) were cut on an ultramicrotome (Reichert Ultracut; Leica, Austria) and placed on nickel grids for immunogold labeling.

\section{Fluorescence Immunohistochemistry}

Sections were incubated for 1 hour with $10 \%$ sodium periodate (Sigma Chemical Company), then washed three times in $10 \mathrm{~mm}$ PBS, $\mathrm{pH}$ 7.3, for 15 minutes. Sections were permeabilized by 15 minutes of incubation in $0.2 \%$ Triton $\mathrm{X}-100$ (repeated three times).
Nonspecific binding sites were blocked with normal rabbit serum in $0.1 \% \mathrm{BSA}$ in $\mathrm{PBS}$, before an overnight incubation at $4^{\circ} \mathrm{C}$ with the primary antibody (LCS3, a polyclonal sheep serum raised against full length human ANX-1), diluted 1:2000 in 0.1\% BSA in PBS. Sections were washed in PBS for 15 minutes before incubation for 1 hour at room temperature with the secondary antibody, a FITC-conjugated rabbit IgG anti-sheep IgG (Sigma Chemical Company), diluted 1:50. Sections were washed again in PBS for 15 minutes and mounted in Citifluor (Stanstead, Essex, United Kingdom). Control sections were incubated with non-immune sheep serum (NSS) (Sigma Chemical Company) rather than LCS3, at the same dilution $(1: 2000)$. Sections were examined in an Olympus $\mathrm{BH}-2-\mathrm{RFCA}$ model fluorescence microscope.

\section{Post-Embedding Immunogold Labeling}

For ANX-1 detection, we used an established immunogold procedure, with slight modifications (Oliani et al, 1997). The specific anti-ANX-1 antiserum, LCS3, has been successfully employed for EM analysis of an epithelial cell line (Traverso et al, 1998) and of human neutrophils (Perretti et al, 2000).

Sections of mesentery were prepared for EM by standard methods. Briefly, mesenteries were stained with uranyl acetate ( $2 \% \mathrm{w} / \mathrm{v}$ in distilled water), dehydrated through increasing concentrations of ethanol (70\% to $100 \%)$ and embedded in LR Gold resin. Ultrathin sections were prepared and incubated at room temperature with $0.1 \mathrm{M}$ phosphate buffer containing $0.1 \%$ egg albumin (PBEA); $2.5 \%$ normal rabbit serum in PBEA for 1 hour; two different anti-ANX-1 antibodies diluted 1:300 in PBEA: LCS3 and LCPS1, a sheep polyclonal antibody raised against the $\mathrm{N}$-terminal peptide of human ANX-1 (peptide Ac2-26) (Perretti and Flower, 1996; Perretti et al, 1996a). NSS, diluted 1:300 was used as control. After five 3-minute washes in PBEA, a 1:50 dilution in PBEA donkey anti-sheep IgG (Fc-fragment specific) antibody conjugated to 15-nm colloidal gold (British Biocell, Cardiff, United Kingdom) was added and sections were incubated for 1 hour at $4^{\circ} \mathrm{C}$. Sections were extensively washed in PBEA and then in distilled water. Ultrathin sections were stained with uranyl acetate and lead citrate before examination on a Jeol 1200 EX II electron microscope (Tokyo, Japan) at $60 \mathrm{kV}$.

\section{NonRadioactive ISH with Oligonucleotide Probes}

Fragments of rat mesenteries (flat mount preparations) were processed for ISH. The fragments were postfixed in $4 \%$ paraformaldehyde and $0.5 \%$ glutaraldehyde in $0.1 \mathrm{M}$ sodium cacodylate buffer, $\mathrm{pH} 7.4$, for 2 hours at $4^{\circ} \mathrm{C}$. After fixation, the fragments were mounted on Superfrost slides (BDH Laboratory Supplies, Poole, Dorset, United Kingdom) and immersed overnight in PBS containing $20 \%$ sucrose (sterile) at $4^{\circ} \mathrm{C}$. Hybridization histochemistry was carried out according to Trembleau and Bloom (1995). The oligonucleotide probes were synthesized and purified com- 
mercially (Genosys, Cambridge, United Kingdom) and were directed against the $\mathrm{N}$ terminal domain of ANX-1. Antisense probe: 5'-GCA GGC CTG CTT GAG GAA TTC TGA TAC CAT TGC C-3'. Sense probe: 5'-CGT CCG GAC GAA CTC CTT AAG ACT ATG GTA ACG G-3'. Oligonucleotides were labeled by tailing the $3^{\prime}$ end with terminal transferase (Roche, Dagenham, United Kingdom) and digoxigenin 11-dUTP (Roche). Oligonucleotide probes were checked against the Genebank database to eliminate sequences presenting obvious homologies with other known probes. Fragments were washed with PBS and treated with $0.3 \%$ Triton $\mathrm{X}-100$ in PBS for 30 minutes at room temperature. Flat mounts were incubated in prehybridization buffer (4x SSC, 1x Denhardt's solution, 10 $\mu \mathrm{g} / \mathrm{ml}$ of denatured yeast tRNA, $1 \mu \mathrm{g} / \mathrm{ml}$ of denatured salmon sperm DNA) at $37^{\circ} \mathrm{C}$ for 2 hours before an overnight incubation at $37^{\circ} \mathrm{C}$ with 20 to $40 \mathrm{~nm}$ labeled oligonucleotides in hybridization buffer $(50 \%$ formamide; $80 \mathrm{~mm}$ Tris- $\mathrm{HCl}, \mathrm{pH} 7.6 ; 10 \mu \mathrm{g} / \mathrm{ml}$ of tRNA; 600 mм NaCl; 0.1\% SDS; 4 mм EDTA).

After hybridization, samples were washed in 2x SSC and placed in $0.1 \%$ SSC at room temperature. After washing in $0.1 \mathrm{M}$ Tris buffer for 20 minutes, slides were soaked in blocking solution (100 mm Tris- $\mathrm{HCl}$, pH 7.5; $150 \mathrm{~mm} \mathrm{NaCl} ; 1 \% \mathrm{BSA}$ ) for 30 minutes at room temperature. Slides were immersed in antidigoxigenin alkaline phosphatase conjugate (Roche), diluted 1:500 in blocking buffer for 2 hours at room temperature. Slides were washed in Buffer A $0.1 \mathrm{M}$ Tris- $\mathrm{HCl}, 1 \mathrm{M} \mathrm{NaCl}, 2 \mathrm{~mm} \mathrm{MgCl}$, $1 \%$ BSA, $0.1 \%$ Triton $\mathrm{X}$-100) for 10 minutes before washing with detection buffer (100 mm Tris, $\mathrm{pH}$ 9.5; $100 \mathrm{~mm} \mathrm{NaCl;} 50 \mathrm{~mm}$ $\mathrm{MgCl}_{2}$ ). Slides were reacted in a detection solution containing $360 \mathrm{mg} / \mathrm{ml}$ of nitro blue tetrazolium and 140 $\mathrm{mg} / \mathrm{ml}$ of 5-bromo-6-chloro-3-indolyl phosphate p-toluidine salt (Roche) for 48 hours at room temperature. The preparations were mounted and coverslipped with Glycergel media (Sigma Chemical Company). The same sections were stained with $1 \%$ toluidine blue in 1\% Borax solution (TAAB Laboratories, Aldermaston, Berkshire, United Kingdom).

\section{Data Handling and Statistical Analysis}

Randomly photographed sections of rat tissues were used. The area of each cell compartment was determined with a point-counting morphometric method using a square test grid with $8.7-\mathrm{mm}$ spacing. The density of immunogold (number of gold particles per $\mu \mathrm{m}^{2}$ ) was calculated and expressed for each compartment. Values are reported as mean \pm SEM of $n$ number of electron micrographs. Statistical differences in the density of gold particles were determined by analysis of variance followed, where significant, by the Bonferroni test. A probability value less than 0.05 was taken as significant.

\section{Acknowledgements}

The expert technical assistance of Lynne Scott and Sarah Rodgers is gratefully acknowledged.

\section{References}

Ahluwalia A, Buckingham JC, Croxtall JD, Flower RJ, Goulding NJ, and Perretti M (1996). Biology of annexin 1. In: Seaton BA, editor. Annexins: Molecular structure to cellular function. Austin: RG Landes, 161-199.

Becherucci C, Perretti M, Solito E, Galeotti C, and Parente L (1993). Conceivable difference in the anti-inflammatory mechanisms of lipocortin 1 and 5. Mediat Inflamm 2:109113.

Buckingham JC (1996). Stress and the neuroendocrineimmune axis: The pivotal role of glucocorticoids and lipocortin 1. Br J Pharmacol 118:1-19.

Cirino G, Peers SH, Flower RJ, Browning JL, and Pepinsky RB (1989). Human recombinant lipocortin 1 has acute local anti-inflammatory properties in the rat paw edema test. Proc Natl Acad Sci U S A 86:3428-3432.

Das AM, Flower RJ, Hellewell PG, Teixeira MM, and Perretti M (1997). A novel murine model of allergic inflammation to study the effect of dexamethasone on eosinophil recruitment. Br J Pharmacol 121:97-104.

Di Rosa M and Sorrentino L (1968). The mechanism of the inflammatory effect of carrageenin. Eur J Pharmacol 4:340342.

Fava RA, McKanna J, and Cohen S (1989). Lipocortin I (p35) is abundant in a restricted number of differentiated cell types in adult organs. J Cell Physiol 141:284-293.

Flower RJ and Blackwell GJ (1979). Anti-inflammatory steroids induce biosynthesis of a phospholipase $A_{2}$ inhibitor which prevents prostaglandin generation. Nature 278:456459.

Flower RJ and Rothwell NJ (1994). Lipocortin-1: Cellular mechanisms and clinical relevance. Trends Pharmacol Sci 15:71-76.

Galli SJ, Maurer M, and Lantz CS (1999). Mast cells as sentinels of innate immunity. Curr Opin Immunol 11:53-59.

Goulding NJ, Godolphin JL, Sharland PR, Peers SH, Sampson M, Maddison PJ, and Flower RJ (1990). Antiinflammatory lipocortin 1 production by peripheral blood leucocytes in response to hydrocortisone. Lancet 335:1416 1418.

Harricane MC, Caron E, Porte F, and Liautard JP (1996). Distribution of annexin I during non-pathogen or pathogen phagocytosis by confocal imaging and immunogold electron microscopy. Cell Biol Int 20:193-203.

Kaufman M, Leto T, and Levy R (1996). Translocation of annexin I to plasma membranes and phagosomes in human neutrophils upon stimulation with opsonized zymosan: Possible role in phagosome function. Biochem J 316:36-42.

Kubes P and Granger DN (1996). Leukocyte-endothelial cell interactions evoked by mast cells. Cardiovasc Res 32:699708.

Morand EF, Hutchinson P, Hargreaves A, Goulding NJ, Boyce NW, and Holdsworth S (1995). Detection of intracellular lipocortin 1 in human leukocyte subsets. Clin Immunol Immunopathol 76:195-202.

Oliani SM, Freymüller E, Takahashi HK, and Straus $\mathrm{AH}$ (1997). Immunocytochemical localization of heparin in secretory granules of rat peritoneal mast cells using a monoclonal 
anti-heparin antibody (ST-1). J Histochem Cytochem 45:231235.

Oliani SM, Girol AP, and Smith RL (1995). Gap junctions between mast cells and fibroblasts in the developing avian eye. Acta Anat 154:267-271.

Peers SH, Smillie F, Elderfield AJ, and Flower RJ (1993). Glucocorticoid- and non-glucocorticoid induction of lipocortins (annexins) 1 and 2 in rat peritoneal leucocytes in vivo. $\mathrm{Br} \mathrm{J}$ Pharmacol 108:66-72.

Perretti M (1997). Endogenous mediators that inhibit the leukocyte-endothelium interaction. Trends Pharmacol Sci 18:418-425.

Perretti M, Ahluwalia A, Harris JG, Harris HJ, Wheller SK, and Flower RJ (1996a). Acute inflammatory response in the mouse: Exacerbation by immunoneutralization of lipocortin 1. Br J Pharmacol 117:1145-1154.

Perretti M, Christian H, Wheller SK, Aiello I, Mugridge KG, Morris JF, Flower RJ, and Goulding NJ (2000). Annexin I is stored within gelatinase granules of human neutrophils and mobilized on the cell surface upon adhesion but not phagocytosis. Cell Biol Int 24:163-174.

Perretti M, Croxtall JD, Wheller SK, Goulding NJ, Hannon R, and Flower RJ (1996b). Mobilizing lipocortin 1 in adherent human leukocytes downregulates their transmigration. Nature Med 22:1259-1262.

Perretti M and Flower RJ (1996). Measurement of lipocortin 1 levels in murine peripheral blood leukocytes by flow cytometry: Modulation by glucocorticoids and inflammation. Br J Pharmacol 118:605-610.

Perretti M, Nuti S, and Parente L (1990). Investigation of rat mast cell degranulation using flow cytometry. J Pharmacol Methods 23:187-194.

Philipps C, Rose-John S, Rincke G, Furstenberger G, and Marks $F$ (1989). cDNA-cloning, sequencing and expression in glucocorticoid-stimulated quiescent Swiss 3T3 fibroblasts of mouse lipocortin I. Biochem Biophys Res Commun 159:155162.

Raynal P, van Bergen PMP, Hullin F, Ragab-Thomas JMF, Fauvel J, Verkleij A, and Chap H (1992). Morphological and biochemical evidence for partial nuclear localization of annexin I in endothelial cells. Biochem Biophys Res Commun 186:432-439.
Solito E, de Coupade C, Parente L, Flower RJ, and RussoMarie F (1998). IL-6 stimulates annexin 1 expression and translocation and suggests a new biological role as class II acute phase protein. Cytokine 10:514-521.

Tailor A, Flower RJ, and Perretti M (1997). Dexamethasone inhibits leukocyte emigration in rat mesenteric post-capillary venules: An intravital microscopy study. J Leukoc Biol 62: 301-308.

Tasaka K, Hamada M, and Mio M (1994). Inhibitory effect of interleukin-2 on histamine release from rat mast cells. Agents Actions 41:C26-C27.

Traverso V, Morris JF, Flower RJ, and Buckingham JC (1998). Lipocortin 1 (annexin 1) in patches associated with the membrane of a lung adenocarcinoma cell line and in the cell cytoplasm. J Cell Sci 111:1405-1418.

Trembleau A and Bloom FE (1995). Enhanced sensitivity for light and electron microscopic in situ hybridization with multiple simultaneous non-radioactive oligodeoxynucleotide probes. J Histochem Cytochem 43:829-841.

Utsunomiya I, Nagai S, and Oh-Ishi S (1991). Sequential appearance of IL-1 and IL- 6 activities in rat carrageenininduced pleurisy. J Immunol 147:1803-1809.

Vergnolle N, Coméra C, and Buéno L (1995). Annexin 1 is overexpressed and specifically secreted during experimentally induced colitis in rats. Eur J Biochem 232:603-610.

Vishwanath BS, Frey FJ, Bradbury M, Dallman MF, and Frey BM (1992). Adrenalectomy decreases lipocortin-I messenger ribonucleic acid and tissue protein content in rats. Endocrinology 130:585-591.

Zhang S, Anderson DF, Bradding P, Coward WR, Baddeley SM, MacLeod JD, McGill JI, Church MK, Holgate ST, and Roche WR (1998). Human mast cells express stem cell factor. J Pathol 186:59-66. 